\title{
Analisis Kesulitan Belajar Fisika Konsep Gerak Lurus pada Peserta Didik Kelas X SMA Negeri 1 Konawe Selatan
}

\author{
Zainuddin'); Rini Puspita Sari' ${ }^{2)}$; Abdul Kadir1) \\ 1) Dosen Tadris Fisika, Fakultas Tarbiyah dan Ilmu Keguruan (FTIK), Institut Agama Islam Negeri (IAIN) \\ Kendari; \\ 2) Alumni Tadris Fisika, FTIK IAIN Kendari \\ Email Korespondensi: zainuddin.fisika11@gmail.com
}

\begin{abstract}
This study aims to (1) determine the implementation of physics learning in class X SMA Negeri 1 Konawe Selatan. (2) knowing the level of understanding of students on the concept of straight motion in class X SMA Negeri 1 Konawe Selatan. (3) knowing the form of learning difficulties of students on the concept of straight motion in class X SMA Negeri 1 Konawe Selatan. (4) knowing the physics teacher's efforts to overcome students' learning difficulties in the concept of straight motion in class X SMA Negeri 1 Konawe Selatan. This research was conducted through a qualitative descriptive method carried out at SMA Negeri 1 Konawe Selatan. Physics learning implementation data were obtained through observation sheets and interviews of teachers and students. The data on students' level of understanding were obtained through test results and interviews with teachers and students. Data on the form of learning difficulties were obtained through test results and interviews with teachers and students. Meanwhile, the data of the physics teacher's efforts to overcome the learning difficulties of students was obtained through interviews with physics teachers. The results showed: (1) the implementation of physics learning at SMA Negeri 1 Konawe Selatan was quite good, but there were still some shortcomings, namely the lack of efficient implementation of the learning aspects both from teachers and students. (2) the level of understanding of students on the concept of straight motion is divided into 3 groups, namely understanding the concept, myaconception and not understanding the concept. (3) the form of learning difficulties of students in the concept of straight motion is in the implementation of learning and the ability to solve questions. (4) the efforts made by the physics teacher to overcome the learning difficulties of students with the concept of straight motion, namely; using interesting learning media, distributing printed books to students, providing additional hours of lessons or tutoring, providing remedial teaching, and providing motivation to students. Thus, there are difficulties in learning the physics of the concept of straight motion in class X SMA Negeri 1 Konawe Selatan.

Keywords: Physics Learning Implementation, Straight Motion Concept, Student Learning Difficulties, Physics Teacher Efforts to Overcome Learning Difficulties
\end{abstract}

\begin{abstract}
ABSTRAK
Penelitian ini bertujuan untuk (1) mengetahui pelaksanaan pembelajaran Fisika di kelas X SMA Negeri 1 Konawe Selatan. (2) mengetahui tingkat pemahaman peserta didik pada konsep Gerak Lurus di kelas X SMA Negeri 1 Konawe Selatan. (3) mengetahui bentuk kesulitan belajar peserta didik pada konsep Gerak Lurus di kelas X SMA Negeri 1 Konawe Selatan. (4) mengetahui upaya guru Fisika mengatasi kesulitan belajar peserta didik pada konsep Gerak Lurus di kelas X SMA Negeri 1 Konawe Selatan. Penelitian ini dilaksanakan melalui metode deskriptif kualitatif yang dilaksanakan di SMA Negeri 1 Konawe Selatan. Data pelaksanaan pembelajaran Fisika diperoleh melalui lembar observasi dan wawancara guru dan peserta didik. Data tingkat pemahaman peserta didik diperoleh melalui hasil tes dan wawancara guru dan peserta didik. Data bentuk kesulitan belajar diperoleh melalui hasil tes dan wawancara guru dan peserta didik. Sedangkan data upaya guru Fisika mengatasi kesulitan belajar peserta didik diperoleh melalui wawancara guru Fisika. Hasil penelitian menunjukkan: (1) pelaksanaan pembelajaran Fisika di SMA Negeri 1 Konawe Selatan cukup baik, namun masih ada beberapa kekurangan yaitu belum terlaksanakanya aspek pelaksanaan pembelajaran dengan efisien baik dari guru maupun peserta didik. (2) tingkat pemahaman peserta didik pada konsep Gerak Lurus dibagi dalam 3 golongan yaitu paham konsep, miakonsepsi dan tidak paham konsep. (3) bentuk kesulitan belajar peserta didik pada konsep Gerak Lurus terdapat pada pelaksanaan pembelajaran dan kemampuan menyelesaikan soal-soal. (4) upaya yang dilakukan guru Fisika untuk mengatasi kesulitan belajar peserta didik konsep Gerak Lurus yaitu; menggunakan media pembelajaran yang menarik, membagikan buku cetak kepada peserta didik, memberikan tambahan jam pelajaran atau bimbingan belajar, memberikan pengajaran perbaikan (remedial), dan memberikan motivasi kepada peserta didik. Dengan demikian, terdapat kesulitan belajar Fisika konsep Gerak Lurus pada peserta didik kelas X SMA Negeri 1 Konawe Selatan.
\end{abstract}

Kata Kunci: Pelaksanaan Pembelajaran Fisika, Konsep Gerak Lurus, Kesulitan Belajar Peserta Didik, Upaya Guru Fisika Mengatasi Kesulitan Belajar 


\section{PENDAHULUAN}

Undang-undang nomor 20 tahun 2003 tentang sistem pendidikan nasional menjelaskan bahwa Pendidikan diselenggarakan dengan memberi keteladanan, membangun kemauan, dan mengembangkan kreativitas peserta didik dalam proses pembelajaran, yang mana terdapat proses interaksi peserta didik dengan pendidik dan sumber belajar pada suatu lingkungan belajar baik secara informal, nonformal, maupun formal (SD, SMP, SMA, perguruan tinggi) (Anonim, 2003). Dalam proses pembelajaran tersebut, terdapat berbagai mata pelajaran yang nantinya akan membantu peserta didik untuk dapat berkembang dan menjadi positif di masa depan, mulai dari mata pelajaran non exact (ekonomi, akuntansi, dan ilmu sosial lainnya) hingga mata pelajaran exact (biologi, fisika, kimia, dan ilmu alam lainnya). Salah satu mata pelajaran exact yaitu fisika, merupakan mata pelajaran yang diajarkan di jenjang SMA dan merupakan kelanjutan dari pelajaran Fisika di jenjang SMP. (Hudha et al., 2016) menyatakan bahwa fisika merupakan ilmu pengetahuan eksperimental dimana manusia harus mengamati fenomena alam untuk menemukan pola dan prinsip yang menghubungkan fenomena-fenomena yang terjadi. Setiap fenomena yang dipelajari dalam Fisika membutuhkan pemahaman konsep. Permendiknas Nomor 22 tahun 2006 menyatakan bahwa salah satu tujuan mata pelajaran fisika, khususnya untuk pendidikan jenjang menengah adalah agar peserta didik dapat menguasai konsep dan prinsip fisika serta mempunyai keterampilan mengembangkan pengetahuan dan sikap percaya diri sebagai bekal untuk melanjutkanpendidikan, khususnya pada jenjang yang lebih tinggi serta mengembangkan ilmu pengetahuan dan teknologi (Permendiknas, 2006). Namun, kenyataannya peserta didik menganggap Fisika adalah pelajaran yang menuntut penghafalan banyak rumus dan sangat sulit untuk memahami materi yang ada di dalamnya sehingga berpengaruh pula pada hasil belajarnya.

Dalam sebuah pembelajaran seorang peserta didik kadang menghadapi sebuah hambatan dalam belajar atau yang dikenal dengan istilah kesulitan belajar. Kesulitan tersebut dapat diakibatkan konsep pada materi yang sangat banyak sehingga membuat peserta didik sulit untuk memahami keseluruhan konsep tersebut (Anggraini et al., 2020). Namun, kesulitan belajar ini dapat diminimalisisr salah satunya dengan memunculkan kesadaran peserta didik tentang tujuan belajar yang harusnya berasal dari dirinya sendiri, bukan dari paksaan orang lain (Syam \& Rizalia, 2021).

Kesulitan belajar peserta didik ditunjukkan oleh adanya hambatan-hambatan tertentu untuk mencapai hasil belajar dan dapat bersifat psikologis, sosiologis maupun fisiologis sehingga pada akhirnya dapat menyebabkan prestasi belajar yang dicapainya berada di bawah semestinya (Sari, 2018). Selain itu, jika seorang peserta didik mengalami kegagalan atau kurang berhasil dalam hasil belajar, hal itu berarti ada kesulitan yang dihadapi selama pembelajaran. Kesulitan belajar peserta didik dapat dipengaruhi oleh beberapa faktor diantaranya faktor internal dan faktor eksternal. Faktor internal salah satunya berupa motode mengajar guru. Sedangkan faktor internal salah satunya berupa intelegensi. Guru merupakan faktor penting dalam pendidikan atau proses belajar mengajar. Oleh sebab itu, dalam pelaksanaan pembelajaran metode mengajar guru sangat berpengaruh pada tingkat pemahaman peserta didik dan berdampak pula pada kemampuan peserta didik dalam menyelesaikan soal-soal. Sehingga diperlukan metode mengajar yang efisien mulai dari kegiatan awal pembelajaran, pra pembelajaran, kegiatan inti pembelajaran hingga kegiatan akhir pembelajaran. Kesulitan belajar apabila tidak segera diatasi akan terus-menerus mengganggu peserta didik dalam menerima pengetahuan-pengetahuan baru. Apabila kesulitan belajar tidak diperhatikan oleh guru, maka berakibat semakin bertambahnya materi yang tidak mampu dipahami secara tuntas (Haqiqi \& Sa'adah, 2018).

Salah satu masalah yang dihadapi oleh peserta didik di SMA Negeri 1 Konawe Selatan, diketahui adanya kesulitan belajar peserta didik pada materi Gerak Lurus. Guru menganggap bahwa materi tersebut sulit dipahami oleh peserta didik karena beberapa hal yaitu peserta didik menganggap rumus materi tersebut sangat banyak dan berbelit-belit, peserta didik kurang termotivasi pada materi yang disampaikan, peserta didik kurang berusaha untuk memahami materi tersebut dan peserta didik mendapat kesulitan dalam menetapkan penguasaan bagian-bagian yang sukar dari seluruh bahan yang harus dipelajarinya. Penyebab lain yang dapat menjadi kesulitan belajar peserta didik adalah konsep dasar yang belum dikuasai peserta didik, pengalaman peserta didik yang berhubungan dengan materi serta peserta didik mendapatkan konsep dari sumber belajar yang lain sehingga dianggap dapat membenarkan.

\section{METODE PENELITIAN}

Jenis penelitian yang digunakan adalah penelitian deskriptif. Sedangkan metode yang digunakan adalah metode deskriptif kualitatif. Oleh karena itu jenis data pada penelitian ini adalah data kualitatif berupa hasil observasi, wawancara dan tes kesulitan belajar menggunakan three-tier multiple choie diagnostic instrumen. Sumber data yang diperoeh dari informan merupakan data primer. Informan dalam penelitian ini adalah Kepala Sekolah, guru fisika dan peserta didik kelas X MIA 2 dan X MIA 3 di SMA Negeri 1 Konawe Selatan. Instrumen yang digunakan dalam penelitian ini yaitu lembar observasi, wawancara, dokumentasi, dan tes berbetuk three-tier multiple choice diagnostic, yang memiliki tiga tingkatan yaitu pada tingkat pertama adalah 
pengujian tentang pengetahuan berupa pilihan ganda. Tingkat kedua, alasan siswa dalam memilih jawaban. Tingkat ketiga adalah keyakinan siswa dalam memilih jawaban (Mubarak et al., 2016).

Untuk menemukan kesulitan belajar dalam pelaksanaan pembelajaran, dilakukan observasi terhadap guru dan peserta didik. Sedangkan tes berbentuk three-tier multiple choice diagnostic diberikan kepada peserta didik. Selanjutnya kegiatan wawancara dilakukan kepada seluruh informan untuk mengetahui lebih lanjut kesulitan belajar peserta didik. Analisis data merupakan salah satu yang sangat penting dalam kegiatan penelitian guna untuk mengetahui kesimpulan tentang masalah yang diteliti. Data yang diperoleh dari penelitian ini adalah hasil observasi, wawancara dan hasil tes diagnostic pilihan ganda tiga tingkat.

Tabel 1. Kriteria Tingkat Pemahaman Konsep Peserta Didik

\begin{tabular}{|c|c|c|c|}
\hline Tingkat Pertama & Tingkat Ke Dua & $\begin{array}{lll}\begin{array}{l}\text { Tingkat } \\
\text { (CRI) }\end{array} & & \text { Tiga } \\
\end{array}$ & Kriteria \\
\hline Benar & Benar & Tinggi & Paham Konsep \\
\hline Benar & $\begin{array}{l}\text { Benar } \\
\text { Salah }\end{array}$ & Rendah & $\begin{array}{l}\text { Tidak Paham } \\
\text { Konsep }\end{array}$ \\
\hline Salah & $\begin{array}{l}\text { Benar } \\
\text { Salah }\end{array}$ & & \\
\hline $\begin{array}{l}\text { Benar } \\
\text { Salah }\end{array}$ & $\begin{array}{l}\text { Salah } \\
\text { Benar } \\
\text { Salah }\end{array}$ & Tinggi & Miskonsepsi \\
\hline
\end{tabular}

(Diana et al., 2020)

\section{HASIL PENELITIAN}

1. Analisis Pelaksanaan Pembelajaran Fisika

Analisis pelaksanaan pembelajaran fisika dalam penelitian ini dilakukan dengan menggunakan lembar obeservasi guru dan peserta didik pada saat proses pembelajaran berlangsung. Adapun hasil observasi pelaksanaan pembelajaran fisika dapat dilihat pada grafik berikut:

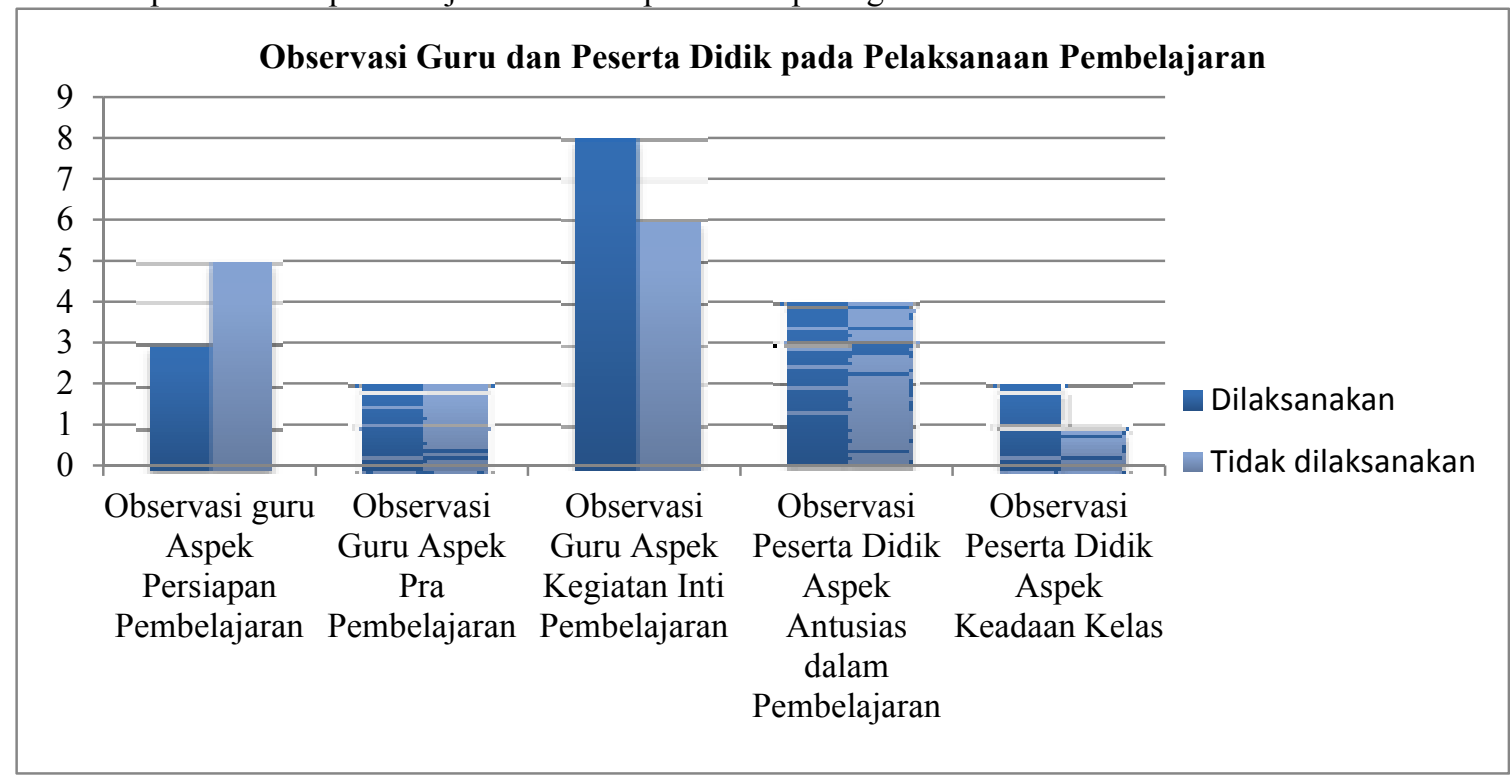

Gambar 1. Grafik Observasi Guru dan Peserta Didik paa Pelaksanaan Pembelajaran

Berdasarkan data hasil observasi di atas, dapat diketahui bahwa banyak aspek atau indikator dalam pelaksanaan pembelajaran yang belum dilaksanakan baik oleh guru maupun peserta didik. Guru belum menciptakan pembelajaran yang efisien mulai dari aspek persiapan pembelajaran, pra pembelajaran hingga kegiatan inti pembelajaran. Sedangkan peserta didik, mulai dari aspek antusias dalam pembelajaran hingga keadaan kelas selama pelaksanaan pembalajaran belum terlaksana dengan baik.

2. Analisis Tingkat Pemahaman Peserta Didik pada Konsep Gerak Lurus

Penelitian ini bertujuan untuk mengetahui tingkat pemahaman konsep peserta didik yang terdiri dari 3 kategori yaitu paham konsep (PK), miskonsepsi (MIS) dan tidak paham konsep (TPK) peserta didik pada materi Gerak Lurus di kelas X MIPA SMANegeri 1 Konawe Selatan. Pada penelitian ini, pengujian tingkat pemahaman konsep peserta didik di ukur dengan tes diagnostik pilihan ganda berdesain three-Tiertest. 
Persentase tingkat pemahaman konsep Gerak Lurus peserta didik yang dijadikan sebagai informan dalam penelitian ini dapat dilihat pada Gambar 2 berkut:

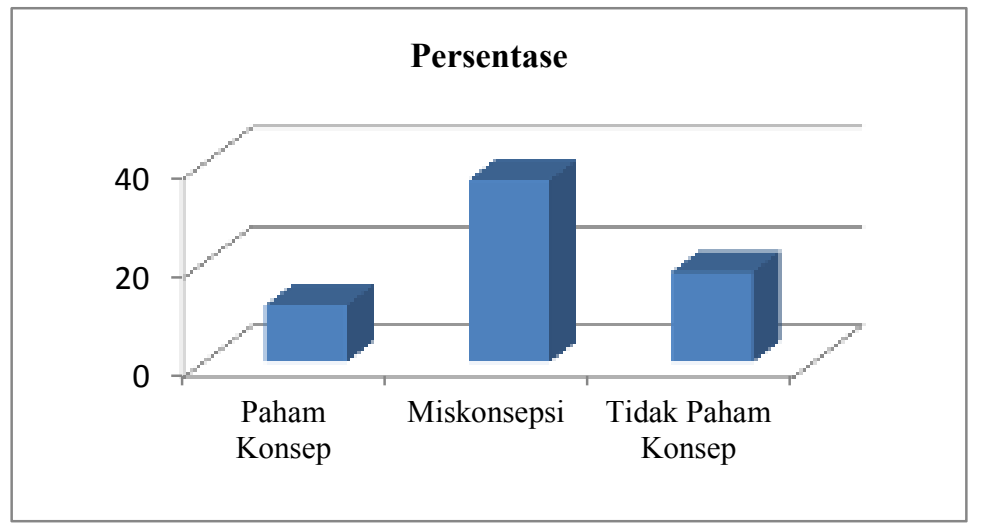

Gambar 2. Persentase tingkat pemahaman peserta didik pada konsep Gerak Lurus

Berdasarkan Gambar 2dapat dilihat bahwa rata-rata persentase tingkat pemahaman peserta didik pada konsep Gerak Lurus di kelas X SMANegeri 1 Konawe Selatan adalah sebesar 11,8 \% untuk kategori paham konsep, 36,7\% untuk kategori miskonsepsi dan 18,1\% untuk kategori tidak paham konsep (TPK). Dengan persentase tingkat pemahmaan peserta didik yaitu 22,2\% dengan kriteria tingkat pemahaman rendah. Hasil ini juga Menunjukkan bahwa tingkat pemahaman peserta didik lebih cenderung didominasi golongan miskonsepsi dengan kategori rendah.

3. Analisis Bentuk Kesulitan Belajar Peserta Didik pada Konsep Gerak Lurus

Berdasarkan hasil observasi langsung yang dilakukan oleh peneliti, terdapat beberapa bentuk kesulitan belajar fisika materi Gerak Lurus yang di alami oleh peserta didik kelas X SMA Negeri 1 Konawe Selatan diantaranya yaitu: (1) kesulitan belajar dalam pelaksanaan pembelajaran. Hal ini dapat dibuktikan dari data hasil observasi yang menunjukkan bahwa baik guru dan peserta didik belum melaksanakan proses pembelajaran dengan efisien shingga peserta didik tidak memiliki minat dan motivasi belajar fisika serta peserta didik menganggap bahwa penjelasan guru masih sulit untuk dipahami karena kurangnya gambar-gambar yang dapat mendukung penjelasan guru tersebut, (2) kesulitan belajar dalam menyelesaiakan soal. Hal ini dapat dilihat dari hasil wawancara terhdap guru dan peserta didik bahwa: (a) Materi Gerak Lurus, karena peserta didik kurang paham konsep dasarnya, (b) Sebenarnya tingkat pemahaman peserta didik itu beda-beda ya. Hanya kalau secara umum dan sebagian besar peserta didik itu tidak paham konsep sehingga dalam menyelesaiakan soal juga terhambat. Dan untuk kemampuan matematis sebagian peserta didik masih rendah, peserta didik tidak paham konsep atau maksud dari soal tersebut dan mereka lambat dalam berhitung.

4. Upaya Guru Fisika Mengatasi Kesulitan Belajar dalam Pembelajaran Fisika Konsep Gerak Lurus

Untuk melihat upaya yang dilakukan guru fisika dalam mengatasi kesulitan belajar, peneliti melakukan wawancara dan observasi langsung terhadap guru fisika tersebut. Berdasarkan hasil wawancara terhadap guru fisika, dapat diperoleh pernyataan mengenai upaya guru fisika dalam mengatasi kesulitan belajar peserta didik pada pembelajaran fisika konsep gerak lurus yaitu: menggunakan media pembelajaran yang menarik, membagikan buku cetak dan video pembelajaran kepada peserta didik, memberikan tambahan jam pelajaran seperti les tambahan atau bimbingan belajar kepada peserta didik, memberikan pengajaran perbaikan (remedial) dan memberikan motivasi kepada peserta didik.

\section{PEMBAHASAN}

Berdasarkan data hasil penelitian yang dilakukan untuk mengetahui kesulitan belajar fisika pada konsep Gerak Lurus, peneliti menggunakan berbagai intrumen berupa lembar observasi, tes diagnostik, wawancara dan dokumentasi. Berikut adalah pembahasan mengenai data yang diperoleh dari hasil penelitian.

\section{Pelaksanaan Pembelajaran Fisika di SMA Negeri 1 Konawe Selatan}

Pelaksanaan pembelajaran fisika di SMA Negeri 1 Konawe Selatan ditemukan pelaksanaan pembelajaran meliputi persipan pembelajaran, pra pembelajaran dan kegiatan inti pembelajaran. Sedangkan ditinjau dari peserta didik saat pelaksanaan pembelajaran meliputi antusias dalam pembelajaran dan keadaan kelas. Jika dilihat dari hasil penelitian yang dilakukan proses pelaksanaan pembelajaran fisika di SMA Negeri 1 Konawe Selatan dikategorikan sudah cukup baik. Namun, masih ada beberapa kekurangan yang ditemukan yaitu dari aspek pelaksanaan pembelajaran yang belum dilaksanakan dengan efisien. Hal ini dapat dilihat dari lembar observasi dalam pelaksanaan pembelajaran yaitu guru tidak 
menentukan tujuan pembelajaran. (Nurrita, 2018) menyatakan bahwa tujuan pembelajaran dapat membantu guru dalam mendesain sistem pembelajaran untuk melihat keberhasilan belajar peserta didik. Akan tetapi, dalam penelitian ini guru tidak melakukan hal tersebut. Sedangkan untuk peserta didik, dari aspek antusias dalam pembelajaran peserta didik tidak berpartisipasi aktif dalam pembelajaran, peserta didik tidak memiliki minat dan motivasi belajar.

Aspek atau indikator lainnya yang belum dilaksanakan degan baik saat pelaksanaan pembelajaran juga terdapat pada saat peserta didik mengerjakan tugas atau menjawab pertanyaan dari guru, aspek mengajukan pertanyaan ketika ada materi yang tidak dipahami dan aspek menjawab pertanyaan guru secara individual. Sedangkan dalam aspek keadaan kelas, peserta didik cenderung tidak aktif dan tidak komunikatif. Kebanyakan peserta didik hanya ramai berbicara pada saat menjawab salam dan mengisi absen.

Dengan tidak terlaksananya aspek-aspek tersebut tentu menjadi salah satu penyebab kesulitan belajar pada peserta didik terutama pada aspek pelaksanaan pembelajaran. Dimana pelaskanaan pembelajaran yang efektif semestinya baik guru maupun peserta didik dapat bekerja sama melaksanakan aspek-aspek tersebut. Tujuannya agar pembelajaran berlangsung secara interaktif, inspiratif, menyenangkan, menantang, memotivasi, serta memberikan ruang yang cukup untuk dapat mengembangkan minat, bakat dan kreativitas. Tujuan utama dari terlaksananya aspek pembelajaran yaitu agar peserta didik lebih paham terhadap materi dan tujuan pembelajaran dapat tercapai.

2. Tingkat Pemahaman Peserta Didik pada Konsep Gerak Lurus

(Dewi et al., 2012) menyatakan bahwa, dalam belajar fisika, kemampuan pemahaman konsep merupakan syarat mutlak untuk mencapai keberhasilan belajar. Berdasarkan hasil tes yang dilakukan terhadap peserta didik kelas X di SMA Negeri 1 Konawe Selatan, dapat diketahui bahwa tingkat pemahaman peserta didik pada konsep Gerak Lurus yaitu 22,2\% dengan rata-rata nilai akhir peserta didik yaitu 35,8 kriteria rendah. Tingkat pemahaman peserta didik dibagi menjadi 3 golongan yaitu paham konsep, miskonsepsi dan tidak paham konsep. Pada penelitian ini, 11,8\% peserta didik dapat memahami konsep materi Gerak Lurus. Golongan miskonsepsi adalah golongan tingkat pemahaman yang paling tinggi. Sebanyak 36,7\% peserta didik mengalami miskonsepsi pada konsep Gerak Lurus. Untuk golongan tidak paham konsep, 18,1\% peserta didik tidak paham konsep pada materi Gerak Lurus dengan kriteria sangat rendah.Berdasarkan hasil penelitian tersebut, jika dikaitkan dengan toeri yang ada tentu dapat dikatakan bahwa peserta didik kelas X di SMA Negeri 1 Konawe Selatan belum memahami konsep Gerak Lurus sehingga mengalami kesulitan belajar yang dapat menggangu keberhasilan belajarnya.

\section{Bentuk-bentuk Kesulitan Belajar Peserta Didik pada Konsep Gerak Lurus}

(Munirah, 2018) menyatakan bahwa jika seorang peserta didik mengalami kegagalan atau kurang berhasil dalam hasil belajar, hal itu berarti ada kesulitan yang dihadapi selama pembelajaran. Berdasarkan hasil analisi data, ditemukan bahwa ada 2 bentuk kesulitan belajar fisika peserta didik pada konsep Gerak Lurus di kelas X SMA Negeri 1 Konawe Selatan yaitu dalam pelaksanaan pembelajaran dan pada kemampuan menyelesaikan soal-soal.

Pelaksanaan pembelajaran fisika terutama pada konsep Gerak Lurus di SMA Negeri 1 Konawe Selatan dapat dikatakan kurang efektif. Hal ini dibuktikan dengan hasil observasi langsung yang dilakukan oleh peneliti pada saat pelaksanaan pembelajaran. Ada beberapa aspek pelaksanaan pembelajaran yang belum dilakukan oleh guru mulai dari kegiatan awal pembelajaran, pra pembelajaran, kegiatan ini pembelajaran hingga kegiatan akhir pembelajaran. Peserta didik juga mengalami kesulitan belajar pada pelaksanaan pembelajaran materi Gerak Lurus yang dilakukan baik secara langsung (pembelajaran di kelas) maupun secara daring yaitu pada aspek motivasi dan minat serta lingkungan.

Berdasarkan hasil wawancara dengan guru fisika mengatakan bahwa sebagian besar peserta didik hanya menghafal rumus tanpa memahami konsep, sehingga pada saat mengerjakan soal dan lupa rumus peserta didik sudah tidak dapat menyelesaikannya. Berikut adalah penjelasan beberapa indikator kesulitan menyelesaikan soal pada konsep Gerak Lurus. Pertama, kesulitan memahami soal adalah kesulitan yang paling dialami oleh peserta didik dalam menentukan apa yang diketahui dan ditanyakan dalam soal. Kedua, kesulitan menggunakan simbol fisika yaitu kesulitan yang dialami peserta didik dalam menuliskan simbolsimbol yang digunakan untuk fisika. Ketiga, kesulitan dalam menggunakan rumus. Kesulitan ini merupakan kesulitan yang dialami peserta didik ketika menentukan persamaan atau rumus yang akan digunakan serta kesulitan dalam membolak-balikan rumus.Ke empat, kesulitan hitungan yaitu kesulitan yang dialami peserta didik terkait perhitungan untuk menyelesaikan soal. Ke lima, kesulitan dalam menganalisis grafik, yaitu kesulitan yang dialami peserta didik ketika membaca grafik atau gambar.

\section{Upaya Guru Fisika Mengatasi Kesulitan Belajar pada Konsep Gerak Lurus}

Dalam penelitian ini, upaya yang dilakukan guru fisika untuk mengatasi kesulitan belajar peserta didik antara lain, (1) guru memberikan sarana dan prasarana berupa media pembelajaran yaitu buku cetak dan video pembelajaran. Dalam hal ini guru menggunakan media pembelajaran yang menarik agar lebih memudahkan peserta didik untuk dapat memahami materi yang diajarkan dikarenakan peserta didik lebih 
suka melihat animasi-animasi baik gambar atau animasi bergerak atau objek apapun yang dapat dilhat secara langsung terlebih dalam pembelajaran daring ini salah satu cara dalam mengamplikasikannya yaitu dengan menggunakan media pembelajaran yang lebih menarik agar mudah dipahami. Materi Gerak Lurus ini, banyak konsep yang harus dijelaskan menggunakan gambar, animasi atau video pembelajaran. Misalnya dalam membedakan besaran-besaran gerak lurus seperti jarak, posisi dan perpindahan, kelajuan dan kecepatan.(2) pemberian tambahan jam pelajaran atau bimbingan belajar kepada peserta didik tujuan yaitu agar peserta didik tidak mudah melupakan materi yang telah diajarkan dan dapat langsung menemukan jawaban dari apa yang belum dipahami. Fani (2014) mengatakan, kemampuan belajar tiap peserta didik tidaklah sama, ada yang cepat dan ada yang lambat dalam memahami isi pembelajaran. Perbedaan individual itulah yang menyebabkan perlunya bimbingan belajar.(3) remedial yang bertujuan agar peserta didik dapat memperoleh atau mencapai prestasi belajar yang memadai melalui proses tersebut, memperbaiki pemahaman diri dan memperbaiki cara belajar.Selain itu, dalam materi Gerak Lurus, banyak peserta didik yang belum dapat mencapai KKM. Remedial merupakan salah satu cara yang dapat diupayakan oleh guru untuk menangani hal tersebut. Pengajaran perbaikan (remedial) merupakan teknik yang digunakan untuk memberikan pengajaran khusus kepada peserta didik yang mengalami kesulitan belajar dengan maksud untuk memperbaiki, membetulkan atau melengkapi kekurangan yang terjadi pada proses pembelajaran sehingga dapat tercapai hasil belajar yang optimal sesuai kemampuan peserta didik (Nasir, 2017). (4) membeikan motivasi kepada peserta didik. Bentuk motivasi belajar yang diberikan oleh guru fisika di SMA Negeri 1 Konawe yaitu dalam bentuk apreasi kepada peserta didik atas hasil belajar yang baik serta pemisalan-pemisalan untuk menjalaskan materi yang objeknya adalah peserta didik. Motivasi sangat penting dalam kegiatan belajar mengajar, karena motivasi dapat mendorong semangat belajar dan sebaliknya kurang adanya motivasi akan melemahkan semangat belajar. Peserta didik yang belajar tanpa motivasi atau kurang motivasi, dalam belajarnya tidak akan berhasil dengan maksimal (Suharni \& Purwanti, 2014).

\section{KESIMPULAN}

Hasil-hasil temuan penelitian mengenai analisis kesulitan belajar fisika konsep gerak lurus menunjukkan bahwa kesulitan belajar yang dialaimi oleh peserta didik di SMA Negeri 1 Konawe Selatan yaitu siswa kesulitan memahami soal,menggunakan simbol fisika, menggunakan rumus perhitungan untuk menyelesaikan soal dan kesulitan dalam menganalisis grafik. Dari kesulitan-kesulitan yang dihadapi siswa sehingga upaya yang dilakukan guru dalam mengatasi kesulitan belajar tersebut menggunakan media pembelajaran yang menarik, membagikan buku cetak, memberikan les, memberikan remedial dan motivasi.

\section{DAFTAR PUSTAKA}

Anggraini, V. A., Mauliska, N., \& Sholehah, M. (2020). Studi Perbandingan Hasil Belajar Fisika Yang Diajar Menggunakan Model Course Review Horay (CRH) dan Model Number Head Together (NHT) pada Siswa SMA Negeri 11 Kendari. Kulidawa, 1(2), 61-64.

Anonim. (2003). Undang-undang Nomor 20 Tahun 2003 Tentang Sistem Pendidikan Nasional. Departemen Pendidikan Nasional. http://simkeu.kemdikbud.go.id/index.php/peraturan1/8-uu-undang-undang/12-uuno-20-tahun-2003-tentang-sistem-pendidikan-nasional

Dewi, E. Y., Supeno, S., \& Subiki, S. (2012). Peningkatan Kemampuan Kerja Ilmiah dan Hasil Belajar Fisika dengan Model Inkuiri Terbimbing pada Siswa Kelas VIIC SMP Negeri 1 Tapen Bondowoso. Jurnal Pembelajaran Fisika, 1(1), 106-111. https://media.neliti.com/media/publications/119322-ID-pengaruhpenerapan-model-pembelajaran-ko.pdf

Diana, P., Marethi, I., \& Pamungkas, A. S. (2020). Kemampuan Pemahaman Konsep Matematis Siswa: Ditinjau dari Kategori Kecemasan Matematik. SJME (Supremum Journal of Mathematics Education), 4(1), 24. https://doi.org/10.35706/sjme.v4i1.2033

Haqiqi, A. K., \& Sa'adah, L. (2018). Deskripsi Kesulitan Belajar Materi Fisika pada Siswa Sekolah Menengah Pertama (SMP) Di Kota Semarang. THABIEA: JOURNAL OF NATURAL SCIENCE TEACHING. https://doi.org/10.21043/thabiea.v1i1.4044

Hudha, M. N., Yuliati, L., \& Sutopo, S. (2016). Perubahan Konseptual Fisika dengan Authentic Problem Melalui Integrative Learning pada Topik Gerak Lurus pada SMA Suryabuana Malang. Jurnal Inspirasi Pendidikan, 6(1), 733. https://doi.org/10.21067/jip.v6i1.1078 
Mubarak, S., Susilaningsih, E., \& Cahyono, E. (2016). Journal of Innovative Science Education Pengembangan Tes Diagnostik Three Tier Multiple Choice. Journal of Innovative Science Education.

Munirah, M. (2018). Peranan Guru dalam Mengatasi Kesulitan Belajar Siswa. TARBAWI : Jurnal Pendidikan Agama Islam. https://doi.org/10.26618/jtw.v3i02.1597

Nasir, M. (2017). Analisis Kesulitan Belajar dan Miskonsepsi Mahasiswa dalam Praktikum Berbasis Proyek. Edu Sains: Jurnal Pendidikan Sains \& Matematika, 5(1), 56. https://doi.org/10.23971/eds.v5i1.602

Nurrita, T. (2018). Pengembangan Media Pembelajaran Untuk Meningkatkan Hasil Belajar Siswa. MISYKAT: Jurnal Ilmu-Ilmu Al-Quran, Hadist, Syari'ah Dan Tarbiyah, 3(1), 171-187. https://doi.org/10.33511/misykat.v3n1.171

Permendiknas. (2006). Peraturan Menteri Pendidikan Nasional RI Nomor 22 Tahun 2006. Global Shadows: Africa in the Neoliberal World Order.

Sari, K. (2018). Analisis Kesulitan Siswa dalam Menyelesaikan Soal-soal pada Pokok Bahasan Suhu dan Kalor di SMA Negeri 8 Banda Aceh. VI(2), 77-84.

Suharni, S., \& Purwanti, P. (2014). Upaya Meningkatkan Motivasi Belajar Siswa. G-COUNS: Jurnal Bimbingan Dan Konseling, 3(1), 131-145.

Syam, A. N., \& Rizalia, S. (2021). Pengaruh Pembelajaran Daring menggunakan Whatsapp Group terhadap Hasil Belajar Mahasiswa Pendidikan BIologi IAIN Kendari ditinjau dari Kesadaran Metakognitif. Biopedagogia, 3(1), 16-25. 